\title{
IMPLEMENTASI BUDAYA DALAM PERKULIAHAN MENULIS AKADEMIK MAHASISWA BIPA TIONGKOK
}

\author{
Setyawan Pujiono and Pratomo Widodo \\ Universitas Negeri Yogyakarta \\ email: setyawan_p@uny.ac.id
}

\begin{abstract}
Abstrak
Upaya untuk mengenalkan budaya Indonesia kepada penutur asing (BIPA) dapat dilakukan melalui berbagai pendekatan. Salah satu pendekatan yang terbuka luas adalah melalui perkuliahan Menulis Karya Ilmiah (akademik). Tujuan penelitian ini untuk menguraikan implementasi budaya dalam perkuliahan menulis akademik mahasiswa BIPA dan mendeskripsikan topik terkait budaya Indonesia dalam produk karya tulis mahasiswa BIPA. Metode penelitian ini berdasarkan hasil observasi, wawancara, dan studi pustaka dalam proses perkuliahan menulis akademik mahasiswa BIPA. Hasil penelitian menunjukkan selama proses perkuliahan menulis akademik sudah berbasis budaya. Saat perkuliahan, dosen sudah menggunakan materi tentang budaya dan aktivitas mahasiswa (pemilihan ide, pengumpulan data, dan penulisan laporan) sudah beorientasi pada budaya Indonesia (khususnya budaya Jawa). Kemudian, topik produk tulisan mahasiswa juga berbasis budaya seperti perilaku hidup masyarakat Jawa, upacara tradisi, seni tradisi, dan benda-benda (artefak) budaya. Topik budaya dipilih oleh mahasiswa BIPA Tiongkok, karena: a) topik budaya sesuai pilihan mahasiswa, sehingga memotivasi belajar mereka, b) penelitian budaya merupakan materi otentik dan beraneka ragam jenisnya, c) budaya merupakan lahan tumbuhnya nilai-nilai dan kepribadian yang luhur dan mempercepat penyesuaian mahasiswa terhadap masyarakat lingkungannya.
\end{abstract}

Kata kunci: budaya, menulis akademik, BIPA

\section{IMPLEMENTATION OF INDONESIAN CULTURE IN EDUCATION WRITING ACADEMICS FOR CHINESE BIPA STUDENTS}

\begin{abstract}
Efforts to introduce Indonesian culture to foreign speakers (BIPA) can be made through various approaches. One approach that is wide open is through lectures on Writing Scientific Papers (Academic Writing). The purpose of this study is to describe the implementation of cultures in the academic writing classesof BIPA students and to describe topics related to Indonesian cultures in the product of BIPA student research reports. The method of the study is based on the results of observations, questionnaires, and literature study in the academic writing process of BIPA students. The research results show that, during the lecture process, academic writing is based on culture. During classes, lecturers use material about students' cultures and activities (idea selection, data
\end{abstract}


collection, and report writing) which are oriented towards Indonesian cultures (especially Javanese cultures). Then, the topic of students' writing is also based on cultures such as the behavior of the Javanese society, traditional ceremonies, traditional arts, and cultural objects (artifacts). The topic of the culturesis chosen by the Chinese BIPA students because: a) cultural topics are in accord with students' choices, thus motivating their learning, b) cultural research is authentic material and has various types, c) culture is the land for the growth of noble values and personalities and accelerates the adjustment of students to their community.

Keywords: culture, academic writing, BIPA

\section{PENDAHULUAN}

Bahasa adalah bagian dari budaya yang memainkan peran sangat penting di dalamnya. Beberapa ilmuwan sosial berpendapat bahwa tanpa bahasa, budaya tidak akan mungkin terjadi. Bahasa secara simultan mencerminkan budaya penuturnya. Dalam arti luas, bahasa merupakan representasi simbolik dari suatu bangsa, yang mencerminkan latar belakang sejarah, budaya cara hidup, dan cara berpikir masyarakatnya. Brown (1994:165) berpendapat bahwa bahasa adalah bagian dari budaya dan budaya adalah bagian dari bahasa. Keduanya terjalin erat sehingga seseorang tidak dapat memisahkan antara budaya dan bahasa.

Kemampuan berbahasa dalam masyarakat di suatu negara akan mencerminkan tingkat identitas dan kepribadian kehidupan negara tersebut. Artinya, bahasa yang digunakan dalam masyarakat merupakan hasil kebiasaan atau budaya yang sudah ada dalam jati diri masyarakat dan bangsanya. Bahasa memegang peran penting untuk terciptanya masyarakat dan negara yang maju sesuai dengan budayanya masingmasing. Oleh karena itu, bahasa sebagai sistem representasi dari pola pikir merupakan cerminan atau wujud budaya masyarakat penuturnya. Holmes (dalam Thomas dan San Wareing, 1972) merumuskan bahwa kajian bahasa sebagai bagian dari representasi kebudayaan dari masyarakat. Di sini ada penegasan, bahasa merupakan bagian dari kebudayaan (language in culture), bahasa bukan merupakan suatu yang berdiri sendiri (language and culture).

Sayuti (2017) menyatakan bahwa bangsa yang bermartabat adalah bangsa yang menjunjung tinggi budayanya. Paparan tersebut menunjukkan bahwa kemajuan Indonesia sebagai bangsa jelas ditopang oleh manusia-manusia yang berjiwa besar, yang menjunjung tinggi nilai-nilai budaya. Kebudayaan merupakan faktor penting dalam membangun kejayaan bangsa. Melalui jalan kebudayaan, suatu bangsa akan mampu menghargai harkat dan martabat dirinya, sekaligus menghargai perjalanan historis yang telah dilaluinya.

Bersamaan dengannya, kebudayaan memerlukan pemeliharaan, pengembangan, dan pembelajaran sebagai upaya yang memberikan pencerahan terhadap pentingnya nilai budaya. Upaya pendidikan (pembelajaran BIPA) yang 
menempatkan budaya sebagai basisnya meniscayakan individu yang terlibat di dalamnya akan terhindar dari situasi terasing dan atau tercerabut dari nilainilai budaya. Dalam konteks inilah, implementasi pembelajaran BIPA berbasis budaya perlu dilaksanakan sebagai upaya membuka pemahaman nilai-nilai yang terkandung di dalamnya.

Bahasa digunakan untuk berpartisipasi dalam budaya, menggambarkan budaya, menafsirkan budaya dan menanggapi budaya (Moran, 2001). Hal tersebut memungkinkan orang-orang dalam kelompok budaya untuk berbagi ide, informasi, dan transmisi budaya. Budaya dapat didefinisikan sebagai gagasan, kebiasaan, seni dan piranti yang mencirikan kelompok orang dalam periode waktu tertentu. Budaya juga melibatkan sikap, nilai, keyakinan, norma, dan perilaku yang dianut bersama sebuah kelompok tetapi dijaga secara berbeda oleh setiap unit spesifik dalam kelompok bersangkutan dan dikomunikasikan lintas generasi. Selanjutnya, Liu (2017) claims that language is a major medium of cultural communication and transmission. Bahasa merupakan medium utama untuk pertukaran komunikasi antar budaya.

Berdasarkan atas pentingnya bahasa dan budaya sebagai sarana komunikasi dan informasi, maka penting dilakukan upaya konkret dalam proses pembelajaran bahasa. Upaya untuk mengenalkan budaya Indonesia kepada pembelajar BIPA (Bahasa Indonesia bagi Penutur Asing) dapat dilakukan melalui berbagai macam cara. Salah satu upaya untuk mengenalkan budaya Indonesia melalui implementasi budaya dalam pembel- ajaran menulis akademik mahasiswa BIPA. Perkuliahan Menulis Karya Ilmiah (akademik) yang selama ini terkesan formal dan kaku akan menjadi cair dan berterima jika subtansi atau bahan ajarnya berbasis pada budaya Indonesia. Selain itu, produk karya tulis mahasiswa akan menarik, jika pemilihan topik/ materi kajiannya bertitik tolak pada budaya negara yang menjadi tujuan belajarnya. Hal itu untuk memahami lebih dalam tentang nilai-nilai sosial budaya, kekayaan seni, acara tradisi, dan perilaku masyarakatnya.

Alasan mengapa budaya diposisikan sebagai konteks dalam penyusunan tugas akhir mahasiswa BIPA Tiongkok, yakni karena: a) tema budaya sesuai pilihan mahasiswa sehingga memotivasi belajarnya, b) kajian budaya merupakan materi otentik dan jenisnya beragam, c) budaya merupakan produk masyarakat untuk tumbuhnya nilai-nilai dan kepribadian yang luhur, d) budaya akan mempercepat penyesuaian terhadap masyarakat lingkungannya, e) memperluas kesadaran sosial dan komunikasi, dan f) membantu mempelajari dan memahami budaya orang lain. Dalam konteks itulah persoalan budaya dapat digunakan sebagai penguatan jati-diri bangsa menjadi benar-benar tampak dan penting untuk selalu diupayakan melalui pendidikan khusunya pada saat penyusunan Tugas Akhir mahasiswa BIPA Tiongkok.

Mahasiswa BIPA sangat tertarik dan tertantang mempelajari budaya negara yang menjadi tujuan belajarnya. Dalam kondisi apapun, mahasiswa yang datang dan belajar di negara tujuan, tidak mau dianggap gagap bahasa dan budaya. Hal 
itulah yang melatarbelakangi betapa pentingnya pemahaman budaya yang perlu disampaikan kepada mahasiswa BIPA. Terkait dengan hal itulah, artikel ini akan fokus pada dua hal, yaitu mendeskripsikan wujud implementasi budaya Indonesia dalam proses menulis akademik mahasiswa BIPA dan mendeskripsikan kajian budaya Indonesia dalam produk karya tulis akademik mahasiswa BIPA.

\section{METODE}

Penelitian ini merupakan penelitian kualitatif dalam rangka mengungkap dan menyajikan aspek budaya dalam perkuliahan Menulis Akademik Mahasiswa BIPA Program Transfer Kredit Tiongkok. Subjek dari penelitian ini adalah mahasiswa dan dosen pengampu matakuliah Menulis Karya Ilmiah. Matakuliah ini dipilih karena kegiatan menulis akademik (berbahasa) sangat erat kaitannya dengan kemampuan berpikir dan cerminan budaya seseorang.

Teknik yang digunakan dalam pengumpulan data ada tiga, yaitu wawancara, observas, dan studi pustaka. Observasi dilakukan pada saat mahasiswa BIPA Tiongkok melaksanakan perkuliahan Menulis akademik di kelas. Pengamatan dilakukan secara mendalam dan berulang-ulang selama proses perkuliahan Menulis Karya Ilmiah untuk melihat apakah kajian budaya sudah diimplementasikan dalam perkuliahan menulis akademik dan juga melihat tema/topik produk laporan penelitian yang ditulis mahasiswa. Wawancara dan pengamatan dilakukan pada mahasiswa BIPA Tiongkok yang mengikuti Program Transfer Kredit di FBS UNY. Studi pustaka dilakukan untuk mengkaji lebih dalam konsep bahasa dan budaya serta langkah-langkah implementasinya dalam perkuliahan Menulis Karya Ilmiah. Studi pustaka mengkaji teori bahasa dan budaya Indonesia dari berbagai macam sumber/ahli agar diperoleh konsep dan aplikasi yang praktis serta mudah untuk diterapkan dalam proses menulis akademik ketika perkuliahan. Berdasarkan hasil observasi dan studi literatur ini, penulis dapat membahas secara jelas dan konkret upaya penerapan konsep bahasa dan budaya dalam menulis akademik saat perkuliahan pada mahasiswa BIPA Tiongkok.

Penelitian hasil kajian pustaka merupakan penampilan argumentasi penalaran keilmuan yang memaparkan hasil kajian pustaka dan hasil olah pikir peneliti mengenai suatu masalah atau topik kajian. Penelitian kajian pustaka dilakukan melalui penelaahan kritis dan mendalam terhadap bahan-bahan pustaka yang relevan. Telaah pustaka dilakukan dengan cara mengumpulkan data atau informasi dari berbagai sumber pustaka. Bahan-bahan pustaka diperlakukan sebagai sumber ide untuk menggali pemikiran atau gagasan baru, atau sebagai bahan dasar untuk melakukan deduksi dari pengetahuan yang yang telah ada, sehingga kerangka teori baru dapat dikembangkan atau sebagai dasar pemecahan masalah (Suyono, 2009).

Pengumpulan data penelitian ini menggunakan instrumen berupa lembar catatan lapangan. Lembar pencatatan data disusun berdasarkan kebutuhan sesuai topik penelitian. Instrumen tersebut digunakan untuk mencatat 
semua aktivitas perkuliahan menulis mahasiswa BIPA Tiongkok. Kemudian, analisis data dilakukan melalui tiga langkah, yakni langkah persiapan, penganalisisan, dan penyimpulan. Persiapan dilakukan untuk mempersiapkan segala sesuatu yang diperlukan untuk kelancaran kegiatan analisis dan penyimpulan. Langkah penganalisisan, peneliti menentukan tema, mengelompokkan data, dan mereduksi data. Langkah penyimpulan, peneliti menganalisis data kualitatif secara berulang dan terus-menerus sehingga diperoleh simpulan yang benar-benar sesuai hasil penelitian.

\section{HASIL DAN PEMBAHASAN \\ Hasil}

Sesuai dengan fokus penelitian, hasil penelitian mencakup dua aspek, yaitu (a) implementasi budaya dalam perkuliahan menulis akademik mahasiswa BIPA dan (b) topik terkait budaya Indonesia dalam produk karya tulis mahasiswa BIPA. Dua aspek dijabarkan dalam beberapa fakta sebagai berikut. Pertama, Mahasiswa Tiongkok memiliki karakteristik belajar yang berbeda dengan mahasiswa Indonesia. Secara umum mereka kolaboratif, aktif, dan mempunyai tipe pembelajar mandiri. Mereka menyukai modul yang tebal dan jika diberi tugas langsung dikerjakan. Kemampuan membaca dan berbicara cenderung lebih bagus daripada kemampuan menulis. Mereka lebih menyukai belajar secara kontekstual di luar kelas (berwisata). Kedua, Proses perkuliahan dengan pendekatan budaya akan memberikan peluang mengenalkan budaya Indonesia yang beraneka ragam jenisnya.
Mahasiswa akan memahami perilaku/ tata krama saat berkomunikasi dengan orang Indonesia sehingga kemungkinan terjadinya benturan budaya (cross culture) dapat dihindari. Ketiga, topik karya tulis mahasiswa BIPA lebih diarahkan pada kajian bahasa dan budaya Indonesia. Meskipun beberapa mahasiswa ada yang mengambil topik ekonomi, hukum, dan teknologi. Akan tetapi, topik-topik karya tulis mahasiswa berupa budaya, adat dan tradisi, agama, politik, ekonomi, perdagangan, hukum dan undangundang, medis, atau topik lain yang merupakan hasil pencermatan selama berada di Indonesia.

\section{Pembahasan}

\section{Karakteristik Belajar Mahasiswa BIPA Tiongkok}

Program pembelajaran BIPA sudah banyak diselenggarakan di beberapa universitas di Indonesia. Misalnya, sejak tahun 2011 Guangdong University for Foreign Studies (GDUFS) telah menyelenggarakan program kerja sama rutin dengan Universitas Negeri Yogyakarta (UNY) untuk program transfer kredit. Yunan University of Nationalities (YUN) juga mulai bekerja sama dengan UNY untuk program serupa sejak tahun 2013. Selain itu, setiap tahun ada beberapa mahasiswa Tiongkok yang mengikuti program darmasiswa dan belajar bahasa Indonesia di UNY. Minat mahasiswa Tiongkok untuk belajar bahasa dan budaya di Indonesia sangat tinggi. Hal itu dibuktikan banyaknya kerja sama yang terjalin antara universitas di Tiongkok dengan universitas di Indonesia. Peluang kerja sama tersebut dapat bermanfaat untuk 
membuka dan mengenalkan budaya Indonesia kepada negara lain melalui pelajar Asing khususnya mahasiswa Tiongkok ketika berada di Indonesia.

Mahasiswa Tiongkok memiliki karakteristik belajar yang berbeda dengan mahasiswa Indonesia. Pengamatan ini dilakukan selama menjadi pengajar kelas BIPA GDUFS Tiongkok. Secara umum mereka kolaboratif, aktif, dan mempunyai tipe pembelajar mandiri. Mereka menyukai modul yang tebal dan jika diberi tugas langsung dikerjakan. Kemampuan membaca dan berbicara cenderung lebih bagus daripada kemampuan menulis. Mereka lebih menyukai belajar secara kontekstual di luar kelas (berwisata). Untukitu, pengajar BIPA dituntut kreatif menggunakan stimulus baik melalui metode, media, pemilihan materi atau suplemen lain. Dengan karakteristik belajar di luar kelas akan menuntut kreativitas pengajar mengemas perkuliahan yang bermakna melalui kegiatan wisata budaya, kuliner, museum, candi, keraton, dan kunjungan di lingkungan masyarakat secara langsung.

Nurlina (2016:389) menyatakan bahwa mahasiswa asing mempunyai mindset berbeda tentang pendidikan. Mereka mempunyai standar tinggi sehingga ketika pembelajaran yang tidak sesuai akan membuat mereka tidak antusias belajar. Pengajar BIPA dapat menumbuhkan motivasi belajar dengan cara; Satu, penampilan guru yang hangat, menumbuhkan partisipasi positif sehingga pembelajar akan terbangun motivasinya dan terlibat dalam pembelajaran. Kedua, peserta mengetahui maksud dan tujuan pembelajaran sehingga mereka akan terdorong aktif. Ketiga, lembaga penyelengggara BIPA menyediakan fasilitas, sumber belajar, perpustakaan dan lingkungan belajar yang mendukung sehingga peserta merasa nyaman dan terpenuhi keingintahuannya. Keempat, pengajar mengakui keadaan peserta dengan memberikan reward dan punishment sehingga mereka merasa dihargai setiap usaha belajarnya. Kelima, pengajar merancang jenis kegiatan pembelajaran yang menarik, menyenangkan dan menantang. Keenam, penilaian hasil belajar dilakukan secara serius, objektif, terbuka, terukur, dan penjelasan setiap kemajuan dalam belajar.

Belajar bahasa Indonesia dalam program BIPA berbeda dengan belajar bahasa Indonesia pada umumnya. Pengajar harus mampu mengajar secara mudah, menyenangkan, dan menarik bagi mahasiswa. Faktor yang lebih penting lagi yaitu, pengajar perlu persiapan pemahaman lintas budaya dan memilih topik yang menarik. Bagaimanapun pembelajaran akan berhasil jika persiapan pemahaman lintas budaya dan materinya disukai oleh mahasiswa BIPA Tiongkok.

Berdasarkan hal tersebut, sangat penting untuk dipahami oleh para pengajar bahwa mengajar mahasiswa di kelas BIPA Tiongkok memerlukan persiapan pemahaman budaya. Para pengajar hendaknya tidak hanya berharap untuk dipahami oleh mahasiswa mereka. Namun, para pengajar dapat menunjukan bahwa mereka memahami budaya para mahasiswa. Pemahaman lintas budaya yang tercipta di kelas tentu memperlancar komunikasi dan kegiatan belajar. Dengan 
demikian, semua pihak yang terlibat dalam kelas akan merasa senang karena belajar BIPA tidak hanya belajar bahasa Indonesia saja tetapi belajar sosialbudaya masyarakatnya.

Bagi mahasiswa GDUFS, belajar merupakan tanggung jawab dan kebutuhan sehari-hari. Oleh karena itu, mereka tidak mengenal lelah untuk belajar setiap hari. Mereka setiap hari belajar keras sehingga apa yang dia pelajari akan dikuasainya dengan baik. Tentunya ini terkait dengan mindset masing-masing mahasiswa. Jika mindset seperti ini dilakukan secara terus menerus maka akan tercipta suasana belajar yang bermakna. Budaya belajar seperti inilah yang akan membentuk manusia cerdas dan menjadikan bangsa semakin maju.

Mahasiswa GDUFS memiliki semangat dan konsentrasi belajar sangat tinggi. Mereka mengukur kesuksesan belajar bukan dilihat dari Indeks Prestasi Komulatif (IPK) yang tinggi, tetapi mereka belajar untuk menguasai apa yang menjadi tujuan dan cita-cita yang ingin diraihnya. Hal itulah yang menjadikan mahasiswa sadar untuk selalu belajar dan berusaha untuk meraih tujuan hidupnya. Oleh karena itu, nilainilai kejujuran, kerja keras, dan tanggung jawab menjadi pondasi penting untuk meraih kesuksesan masa depan mereka.

Sebelum mahasiswa Tiongkok ke Indonesia, mereka telah belajar bahasa Indonesia selama dua tahun (empat semester) di kampusnya. Mereka telah dibekali berbagai keterampilan bahasa khususnya berbicara, membaca, menulis dan menyimak. Akan tetapi, subtansi materi perkuliahan belum membahas secara mendalam aspek pemahaman budaya terkait negara yang akan dikunjunginya. Upaya untuk memahami budaya secara kontekstual akan diperoleh ketika mahasiswa menempuh perkuliahan di UNY. Oleh karena itu, upaya optimalisasi pemahaman budaya adalah melalui produk karya tulis mahasiswa dalam proses pembelajaran BIPA.

\section{Proses Menulis Akademik Mahasiswa BIPA Berbasis Budaya}

Melalui perkuliahan Menulis Karya Ilmiah, ragam dan cara pengembangan tulisan akademik diajarkan untuk mahasiswa BIPA. Pembelajaran BIPA untuk mahasiswa Program Transfer Kredit Tiongkok perlu dioptimalkan dalam memanfaatkan khasanah budaya Indonesia yang adiluhung. Proses perkuliahan dengan pendekatan budaya akan memberikan peluang mengenalkan budaya Indonesia yang beraneka ragam jenisnya. Mahasiswa akan memahami perilaku/tata krama saat berkomunikasi dengan orang Indonesia sehingga kemungkinan terjadinya benturan budaya (cross culture) dapat dihindari.

Melalui mata kuliah Menulis Karya Ilmiah transfer pengetahuan dan budaya dapat diimplementasikan. Mata kuliah ini tentunya untuk mendukung tugas penulisan laporan penelitian yang menjadi tugas wajib final mahasiswa. Materi ajar dan modul mengenai Menulis Karya Ilmiah menjadi sangat urgen dalam upaya ini. Sementara ini, materi ajar menulis akademik belum optimal dan masih perlu analisis berdasarkan kebutuhan para mahasiswa. Oleh karena itu, pengembangan materi yang berorientasi budaya Indonesia perlu 
menjadi prioritas dalam materi perkuliahan -khususnya penyusunan laporan penelitian/mini proyek- agar berkualitas. Hal lain yang lebih penting tentunya untuk mengenalkan khasanah budaya Indonesia secara mendalam pada mahasiswa BIPA Tiongkok. Hal itu sesuai dengan pernyataan Sayuti (2017:20) bahwa alasan mengapa budaya dan sastra diposisikan sebagai konteks dalam pembelajaran BIPA, yakni karena: a) budaya mampu memotivasi pelajar, $b$ ) budaya merupakan materi otentik, c) budaya mengandung nilai-nilai, d) membantu mempelajari dan memahami budaya orang lain, dan e) memperluas kesadaran bersosial.

Bahan ajar yang digunakan dalam proses pembelajaran menulis akademik Mahasiswa BIPA di FBS UNY sudah dikembangkan dengan beorientasi pada budaya Indonesia (khususnya Yogyakarta). Hasil observasi di kelas, ketika mahasiswa diminta untuk melakukan penggalian ide dalam perkuliahan menulis, bahan ajar sudah diarahkan pada kajian aspek bahasa dan budaya. Kondisi tersebut sesuai dengan pendapat Defina, Rasyid, \& Ridwan, (2018) pemelajar sebagai pengguna materi ajar tertarik dengan materi yang dikembangkan dengan tujuan khusus. Menariknya materi tujuan khusus misal tema budaya mampu memotivasi pemelajar untuk terus belajar.

Aspek-aspek budaya yang sudah digunakan dosen dalam perkuliahan BIPA di FBS UNY misalnya kajian tentang perilaku hidup masyarakat, makanan khas, seni tradisi, bangunan cagar budaya, kepercayaan masyarakat, karya sastra, upacara adat dan gaya hidup masyarakat di wilayah Yogyakarta.
Akan tetapi, masih terdapat pula sebagian mahasiswa yang memilih topik ekonomi, hukum, dan teknologi sebagai bahan untuk menulis. Hal itu disebabkan, karena sebagian mahasiswa sudah diberi pesan oleh dosen dari universitas asalnya untuk mengkaji terkait materi tersebut. Meskipun begitu, kajian-kajian tersebut tidak bisa lepas dari kajian bahasa dan budaya Indonesia meskipun porsinya tidak seluruhnya.

Berdasarkan kajian di atas, Sibarani (2004:59) membagi nilai-nilai budaya yang dapat disampaikan oleh bahasa sebagai jalur penerus kebudayaan terbagi atas tiga bagian kebudayaan yang saling berkaitan, yaitu kebudayaan ekspresi, tradisi, dan fisik. Kebudayaan ekspresi mencakup perasaan, keyakinan, intuisi, ide dan imajinasi kolektif. Tradisi mencakup nilai-nilai religi, adat istiadat, dan kebiasaan-kebiasaan. Kebudayaan fisik/artefak mencakup hasil karya asli atau produk yang dimanfaatkan masyarakat dalam kehidupan seharihari.

Aktivitas pembelajaran menulis akademik berikutnya adalah mahasiswa BIPA melakukan pengumpulan data terkait dengan ide yang sudah diperoleh. Pengumpulan data dilakukan melalui observasi, wawacara dan quesioner. Sebelum terjun ke lapangan, mahasiswa menyusun instrumen yang terkait dengan ketiga kegiatan tersebut dibimbing oleh dosen. Instrumen yang disusun harus memperhatikan kajian/teori terkait aspek-aspek budaya apa saja yang ingin diperoleh saat pengumpulan data. Mahasiswa sangat antusias dan teliti mencermati setiap aspek atau komponen terkait data yang ingin diperoleh. Mereka 
berpikir dan berprinsip bahwa penelitian yang dilakukan harus sangat menarik dan bermanfaat untuk di bawa pulang ke negara asalnya, sehingga instrumen pengumpulan data ditulis dengan sangat teliti dan lengkap.

Kegiatan berikutnya, mahasiswa melakukan pengumpulan data di lapangan. Mahasiswa yang ide penelitiannya terkait dengan seni tradisi, maka mereka akan melakukan observasi langsung ke lokasi dan melakukan wawancara dengan pelaku seni tradisi yang berkompeten. Jika ide penelitian terkait dengan perilaku atau kebiasaan hidup di masyarakat, maka mahasiswa BIPA akan melakukan wawancara atau membagikan questioner ke subjek penelitian yang dipilih di masyarakat secara langsung. Supaya memiliki kompetensi dalam komunikasi lintas budaya, maka mahasiswa harus memahami kebiasaan-kebiasaan sosial budaya dan sistem budaya yang berlaku di daerah tersebut. Sebagai contoh memahami cara berpikir dan perilaku seseorang merupakan suatu hal yang urgen untuk terciptanya hubungan sosial yang humanis. Karena itu, fenomena budaya merupakan salah satu unsur budaya sebagai wujud ekspresi nilai-nilai budaya masyarakat penuturnya. Fenomena-fenomena budaya/perilaku sosial masyarakat tersebut terdapat dalam tugas akhir penelitian mahasiswa BIPA.

Selanjutnya, mahasiswa yang meneliti situs atau tempat bersejarah -Keraton Kesultanan Yogyakarta- akan mendapatkan pengetahuan penting tentang peradaban kehidupan atau budaya masyarakat di sekitar Yogyakarta. Mahasiswa akan belajar kearifan lokal di lingkungan Keraton Yogyakarta melalui wawancara, dokumentasi, dan obervasi lansung ke lokasi. Selama pengumpulan data terkait dengan judul Mini Proyek tersebut, mahasiswa akan memahami berbagai konteks terkait sejarah keraton, upacara ritual, seni pertunjukan, dan perilaku hubungan sosial antara sultan dengan masyarakatnya.

Roger \& Steinfatt (dalam Rokhman, 2012) menyatakan bahwa budaya dapat diberi batasan sebagai keseluruhan cara hidup (the total way of life) yang tersusun berdasarkan pola-pola perilaku, nilainilai, norma-norma, dan objek material yang mereka pelajari dan pertukarkan. Meskipun budaya merupakan sebuah konsep yang sangat umum, tetapi budaya memiliki efek yang sangat kuat terhadap perilaku individu, termasuk perilaku komunikasi. Budaya tidak hanya dimiliki oleh kelompok bangsa atau kelompok etnis, tetapi juga komunitas atau organisasi dan sistem lainnya. Jadi, budaya adalah keadaan sosial budaya pemakainya dan keadaan psikologi yang mempengaruhi perilakunya.

Pada perkuliahan menulis akademik ini berorientasi pada kebutuhan mahasiswa untuk mengenal budaya sekaligus mempercepat penyesuaian terhadap masyarakat lingkungannya. Oleh karena itu, pada kegiatan pengumpulan data dosen harus selalu siap mendampingi dan membimbing jika mahasiswa mengalami kendala di lapangan. Kendala-kendala terkait dengan pengumpulan data oleh mahasiswa BIPA pasti ada dan perlu pembimbingan secara khusus. Kendalakendala yang terjadi akan menjadi pengalaman berharga bagi mahasiswa 
dalam rangka memahami lebih dekat bahasa dan budaya Indonesia khususnya budaya Jawa. Pilihan kata yang digunakan oleh dosen seperti strategi kesopanan di dalam interaksi kelas penting, tidak hanya untuk mengatur proses belajar mengajar, tetapi juga untuk proses penguasaan bahasa itu sendiri (Heriyawati, Siba, dan Sulistyo, 2019).

Setelah tahap pengumpulan data selesai, mahasiswa akan menulis laporan penelitian berdasarkan hasil data yang diperoleh. Mahasiswa menulis laporan penelitian (mini proyek) dalam bahasa Indonesia dan menyesuaikan format penulisan akademik di Fakultas Bahasa dan Seni Universitas Negeri Yogyakarta. Pemilihan bahasa Indonesia untuk penulisan laporan penelitian bertujuan agar mahasiswa semakin mahir kemampuan menulis akademik menggunakan bahasa Indonesia. Selain itu, mahasiswa BIPA Tiongkok ke Indonesia tujuan utamanya adalah belajar bahasa Indonesia, sedangkan materi budaya untuk semakin mendekatkan dan mempermudah mahasiswa belajar bahasa Indonesia.

Menurut hipotesis Sapir-Whorf (1921), sebenarnya setiap bahasa menunjukkan suatu dunia simbolik yang khas dan melukiskan realitas pikiran, pengalaman batin, dan kebutuhan pemakainya. Bahasa dapat mempengaruhi pemakainya dalam berpikir, melihat lingkungannya, dan alam sekitarnya. Worf (1921) sampai pada simpulan bahwa, (1) tanpa bahasa kita tidak dapat berpikir, (2) bahasa mempengaruhi tindakan dan persepsi, dan (3) bahasa mempengaruhi pola pikir.

Inti dasar kebudayaan adalah segala sesuatu dalam rangka kehidupan masyarakat sebagai hasil proses belajar (Sibarani, 2004:210). Sesuatu yang dimaksud adalah ide, tindakan, dan hasil karya manusia. Ketiganya tercipta dan bermanfaat dalam kehidupan manusia karena interaksi antar manusia di dalam masyarakat itu. Interaksi antar manusia akan terwujud apabila ada proses komunikasi. Tiada interaksi tanpa komunikasi. Komunikasi dan interaksi untuk menuangkan ide/gagasan, tindakan dan karya adalah bahasa. Hal ini dipertegas Levi-Strauss (melalui Sibrani, 2004:62) bahwa bahasa yang dipergunakan atau diucapkan oleh kelompok masyarakat adalah suatu refleksi atau cermin keseluruhan kebudayaan masyarakat tersebut.

Untuk mengkaji bahasa \& budaya terdapat kecenderungan dalam analisisnya yaitu antropolinguistik (penekanan pada kajian budaya) dan linguistik antropologi (penekanan pada kajian linguistik). Brown (2007) merumuskan keterkaitan antara bahasa dan kebudayaan dengan pengajaran bahasa, salah satunya tampak dari delapan kriteria aktivitas dalam pembelajaran seperti: 1) menghargai data dan sistem kepercayaan yang dianggap menjadi bagian budaya mahasiswa, 2) tidak merendahkan stereotip budaya lain, termasuk budaya mahasiswa, 3) tidak merendahkan bahasa asli mahasiswa, 4) mengakui berbagai tingkatan kesediaan mahasiswa berpartisipasi secara terbuka karena faktor kolektivisme/individualisme dan jarak kekuasaan, 5) jika aktivitas tersebut mengharuskan mahasiswa beranjak dari budaya mereka, hal ini dilakukan secara empiris dan 
bijaksana, 6) peka terhadap perbedaan gender dalam budaya mahasiswa, 7) menghubungkan ciri-ciri bahasa spesifik (tata bahasa, leksikon, dan wacana) dengan cara berpikir, merasa, dan bertindak yang kultural, dan 8) memanfaatkan pengalaman-pengalaman dari latar belakang budaya mahasiswa yang berbeda-beda.

\section{Topik Karya Tulis Mahasiswa BIPA Tiongkok}

Produk akhir kuliah menulis akademik mahasiswa BIPA Tiongkok adalah laporan penelitian/mini proyek. Laporan penelitian ini sebagai tugas akhir mata kuliah Menulis Karya Ilmiah yang kemudian ditindaklanjuti sebagai tugas akhir mahasiswa untuk menyelesaikan program transfer kredit selama satu tahun di FBS UNY. Tugas akhir penulisan laporan penelitian yang diprogramkan oleh FBS UNY untuk memberikan kesempatan pada mahasiswa transfer kredit menulis ilmiah dengan topik yang diminati. Topik karya tulis mahasiswa BIPA lebih diarahkan pada kajian bahasa dan budaya Indonesia. Meskipun beberapa mahasiswa ada yang mengambil topik ekonomi, hukum, dan teknologi. Akan tetapi, topik-topik karya tulis mahasiswa berupa budaya, adat dan tradisi, agama, politik, ekonomi, perdagangan, hukum dan undangundang, medis, atau topik lain yang merupakan hasil pencermatan selama berada di Indonesia.

Karena tinggal di Indonesia, mahasiswa memiliki kesempatan untuk mengumpulkan data sesuai dengan kebutuhan penelitian mereka untuk penulisan laporan penelitian, misalnya wawancara dengan orang Indonesia, observasi tempat tertentu, melakukan survei, dan lain-lain. Produk laporan penelitian (mini proyek) ini akan diajukan sebagai skripsi mahasiswa ketika mereka kembali ke Tiongkok. Oleh karena itu, upaya maksimal dari mahasiswa selama di Indonesia dilakukan agar karya tulis (laporan penelitian) yang dihasilkan dapat diterima oleh dosen di Tiongkok sebagai skripsi mereka. Upaya ini juga dilakukan oleh para dosen menulis, para pembimbing tugas akhir, para tutor, serta humas kerja sama agar kualitas karya laporan penelitian mereka berkualitas dan meningkat dari tahun ke tahun.

Melalui mata kuliah Menulis Karya Ilmiah, berbagai strategi dan cara dilakukan untuk mengembangkan kemampuan menulis akademik mahasiswa BIPA program transfer kredit. Mata kuliah ini tentunya sangat mendukung tugas penulisan laporan penelitian atau mini proyek yang menjadi tugas wajib akhir mahasiswa. Oleh karena itu, kajian dalam penelitian mahasiswa BIPA diarahkan pada konteks bahasa dan budaya Indonesia. Hal itu bertujuan agar mahasiswa senang belajar budaya Indonesia agar mudah beradaptasi dan berkomunikasi dengan masyarakat Indonesia.

Pernyataan di atas sesuai pendapat Koentjaraninrat (2016) bahwa kebudayaan sebagai sistem gagasan, tindakan dan hasil karya manusia dalam rangka kehidupan nasyarakat yang dijadikan milik manusia dengan belajar. Pemerolehan kebudayaan melalui proses belajar mengimplisitkan adanya proses komunikasi menggunakan bahasa. Bahasa diartikan sebagai sebuah cara 
untuk mendeskripsikan dan memberikan informasi tentang dunia yang ada di sekitar kita. Dalam kehidupan seharihari, kita memerlukan bahasa sebagai sarana komunikasi. Bahasa terikat oleh konteks budaya yang perlu dikuasai dan dimengerti oleh seseorang dalam tindak berkomunikasi di masyarakat. Oleh karena itu, banyak ilmuwan yang meneliti pentingnya peran bahasa dalam berbagai lingkup bidang.

Pembelajaran BIPA untuk mahasiswa program transfer kredit Tiongkok perlu dioptimalkan dalam memanfaatkan khasanah budaya Indonesia yang adiluhung. Proses perkuliahan dengan pendekatan budaya akan memberikan peluang mengenalkan budaya Indonesia yang beraneka ragam jenisnya. Peserta didik akan memahami perilaku/tata krama saat berkomunikasi dengan orang Indonesia sehingga kemungkinan terjadinya benturan budaya (cross culture) dapat dihindari.

Upaya Pembelajaran BIPA dengan pendekatan budaya dapat dilakukan pula dengan pemilihan topik yang tepat dan disenangi. Secara umum pembelajaran bahasa Indonesia bagi mahasiswa BIPA Tiongkok diberikan dengan dasar tematik. Hasil Penelitian menunjukan, secara berurutan tema Mini Proyek yang paling disukai mahasiswa BIPA Tiongkok adalah budaya, wisata bersejarah, kuliner, seni tradisi, hiburan, ekonomi, kesehatan, sosial, dan politik (Kusmiatun, 2015). Namun demikian, pengajar memiliki kewenangan dalam mengembangkan materi yang ada. Terkait dengan hasil penelitian di atas, dalam kegiatan menulis, tema budaya menjadi prioritas pertama pilihan mahasiswa dalam penulisan Mini
Proyek mereka.

Eksplorasi minat topik belajar yang dimiliki mahasiswa GDUFS selama belajar bahasa Indonesia ini merupakan kajian yang sangat bermanfaat untuk menyiapkan kelas yang lebih bermakna. Pengajar dapat memahami keinginan dan memadukan dengan kebutuhan mahasiswa GDUFS dalam belajar bahasa Indonesia. Selain itu, pemahaman budaya dari hasil laporan penelitian atau mini proyek mahasiswa dapat digunakan untuk sarana menjalin komunikasi dan kerja sama antara Indonesia dan Tiongkok.

Konsep budaya dapat ditinjau dari kajian filsafat, sosiologi, antropologi, sastra dan studi budaya. Akan tetapi, dua pandangan besar yang biasa digunakan adalah konsep budaya humanistik dan antropologis. Konsep budaya humanistik menangkap 'budaya heritage 'sebagai model kehalusan, koleksi eksklusif mahakarya komunitas dalam sastra, seni rupa, musik, dll. Konsep antropologi kebudayaan mengacu pada keseluruhan jalan hidup komunitas atau masyarakat, yaitu, semua yang tradisional, eksplisit dan implisit desain untuk hidup yang bertindak sebagai panduan potensial untuk perilaku (House, 2007:8).

Supaya memiliki kompetensi dalam komunikasi lintas budaya, maka pembelajar harus memahami kebiasaankebiasaan sosial budaya dan sistem budaya yang berlaku di daerah tersebut. Sebagai contoh memahami cara berpikir dan perilaku seseorang merupakan suatu hal yang urgen untuk terciptanya hubungan sosial yang humanis. Karena itu, fenomena budaya merupakan salah satu unsur budaya sebagai wujud ekspresi 
nilai-nilai budaya masyarakat penuturnya. Fenomena-fenomena budaya/ perilaku sosial masyarakat tersebut dapat menjadi kajian penelitian atau research mahasiswa BIPA. Topik-topik terkait keberagaman budaya Indonesia yang dikembangkan dalam penelitian mahasiswa disajikan pada Tabel 1.

Tabel 1 Topik Karya Tulis Akademik Mahasiswa BIPA Berbasis Budaya

\begin{tabular}{|c|c|}
\hline Ragam Budaya & Judul Karya Tulis Akademik \\
\hline \multirow[t]{8}{*}{ Perilaku Hidup } & Perkembangan Jasa Laundry di Kota Yogyakarrta \\
\hline & Analisis Akulturasi Budaya Hokian Masyarakat di Indonesia \\
\hline & Poligami di Indonesia \\
\hline & Obat Tradisional di Indonesia \\
\hline & Budaya Memakai Kosmetik Pemutih Wajah pada Mahasiswi di \\
\hline & Yogyakarta \\
\hline & Kehidupan Tukang Becak di Yogyakarta \\
\hline & Tingkat Konsumtif Mahasiswa UNY melalui Belanja Online \\
\hline \multirow{4}{*}{$\begin{array}{l}\text { Kepercayaan/Upacara } \\
\text { Adat }\end{array}$} & Kepercayaan Mayarakat Yogyakarta terhadap Gunung Merapi \\
\hline & Upacara Kematian Tradisional agama Islam di Pulau Jawa \\
\hline & Upacara Pernikahan Suku Jawa \\
\hline & Makna Upacara Tujuh Bulanan Masyarakat Jawa \\
\hline \multirow[t]{5}{*}{ Seni Tradisi/Pertunjukan } & Sosok Dewa Ruci dalam Wayang \\
\hline & Nilai-nilai moral dalam Cerita Ramayana \\
\hline & $\begin{array}{l}\text { Seni Tradisional drama Tari } M u \text { Ou (Tiongkok)dan Wayang Golek } \\
\text { (Indoneisa) }\end{array}$ \\
\hline & Nilai Ritual dalam Tari Pertujukan di Keraton Yogyakarta \\
\hline & Karakter Tokoh pandawa dalam Cerita Wayang \\
\hline \multirow{8}{*}{$\begin{array}{l}\text { BendaTradisi atau Artefak } \\
\text { (keraton, rumah, pasar, } \\
\text { dan pakaian) }\end{array}$} & Filosofi Arsitektur Rumah Tradisional Jawa \\
\hline & Sejarah Keraton Kesultanan Yogyakarta \\
\hline & Perbedaan antara Rumah Limasan di Jawa dengan \\
\hline & Rumah Suku Dai di Tiongkok \\
\hline & Pasar Tradisional di Yogyakarta \\
\hline & PerkembanganTransportasi Andong di Yogakarta \\
\hline & Nilai Filosofi Batik Yogyakarta \\
\hline & Corak Batik Madura dan Maknanya \\
\hline
\end{tabular}


Selain itu, pemahaman budaya melalui karya sastra dapat pula dijadikan strategi mengenalkan dan memahami budaya masyarakatnya. Menurut Suminto (2017:4) dalam perspektif sosiologis, sastra merupakan refleksi dan refraksi masyarakat. Dengan demikian, penelitian terhadap karya sastra dapat diperhitungkan sebagai dokumen yang merepresentasikan realitas sosial budaya, walaupun pada akhirnya karya tersebut diposisikan sebagai karya fiksi. Terlebih lagi jika disadari bahwa hubungan dengan "dunia nyata" bersifat tidak langsung. Bahkan secara struktural teksteks sastra menciptakan maknanya dengan berorientasi pada bahasa itu sendiri (Widdowson, 1984).

Nurgiyantoro (2019) menjelaskan bahwa sastra dapat muncul dari masyarakat yang telah memiliki konvensi, tradisi, pandangan estetik, tujuan sastra, dan lain-lain yang dapat dilihat sebagai realisasi budaya. Aspek budaya dapat juga merupakan representasi dari penulisnya (sastrawan) dari sebuah lingkungan asal usulnya yang khas. Untuk itu, pemilihan karya sastra bermuatan budaya sebagai objek penelitian dan Mini Proyek mahasiswa BIPA Tiongkok harus benar-benar dipilih yang sesuai dengan karakter pembelajar. Bahkan ada pula karya sastra yang muatan budayanya bertentangan dengan budaya peserta BIPA sehingga akan menimbulkan benturan budaya. Oleh karena itu, karya sastra bermuatan budaya yang dipilih hendaknya mengandung nilai-nilai tata krama, tradisi-tradisi (local wisdom), dan praktikpraktik sosial yang khas bersifat keindonesiaan.

\section{SIMPULAN}

Budaya Indonesia (khususnya budaya Jawa) sudah diimplementasikkan dalam perkuliahan Menulis Karya Ilmiah (akademik) mahasiswa BIPA Tiongkok di Fakultas Bahasa dan Seni Universitas Negeri Yogyakarta. Bentuk implementasi budaya tersebut dapat diketahui saat proses perkuliahan dan pada produk karya tulis mahasiswa BIPA Tiongkok. Dosen selama proses perkuliahan Menulis Karya Ilmiah (akademik), sudah menggunakan materi dan bahan ajar tentang budaya. Saat perkuliahan pun, aktivitas mahasiswa (pemilihan ide, pengumpulan data, dan penulisan mini proyek) sudah beorientasi pada budaya Indonesia (khususnya budaya Jawa).

Topik karya tulis mahasiswa berorientasi pada tiga komponen budaya yaitu nilai-nilai budaya, tindakan atau perilaku budaya, dan Benda budaya atau artefak. Kemudian, produk karya tulis akademik mahasiswa BIPA Tiongkok sudah berbasis budaya seperti perilaku hidup masyarakat Jawa, upacara tradisi, seni tradisi, dan benda-benda atau artefak (candi, keraton, musium, batik, baju adat, dll). Selain itu, alasan penting topik budaya dipilih oleh mahasiswa BIPA Tiongkok, karena: a) topik budaya sesuai pilihan mahasiswa, sehingga memotivasi belajar mereka, b) penelitian budaya merupakan materi otentik dan beraneka ragam jenisnya, c) budaya merupakan lahan tumbuhnya nilai-nilai dan kepribadian yang luhur dan mempercepat penyesuaian mahasiswa terhadap masyarakat lingkungannya. 


\section{UCAPAN TERIMA KASIH}

Penulis mengucapkan terima kasih kepada seluruh pihak yang telah berperan dalam membantu penelitian dan penulisan artikel ini. Ucapan terima kasih disampaikan kepada teman sejawat yang telah menelaah artikel ini. Selanjutnya, ucapan terima kasih juga disampaikan kepada reviewer dan editor jurnal LITERA yang telah membaca, mengoreksi, dan mereview artikel penelitian ini sehingga artikel ini bisa terbit. Terima kasih.

\section{DAFTAR PUSTAKA}

Boas, F. (1974) "The History of Anthropology," in A Franz Boas Reader: The Shaping of American Anthropology, 1883-1911, ed. George W. Stocking, Jr (Chicago, IL: University of Chicago Press).

Brown, H. D. (2007). Prinsip Pembelajaran dan Pengajaran Bahasa. Edisi Kelima. Penerjemah: Noor Cholis dan Yusi AviantoPareanom. Jakarta: Kedutaan Besar Amerika Serikat.

Chaer, A. (2009). Psikolinguistik: Kajian Teoritik. Jakarta: Rineke Cipta.

Cummings, L. (2007). Pragmatik: Sebuah Perspektif Multidisipliner. Yogyakarta: Pustaka Pelajar.

Defina, Rasyid, Y., dan Ridwan, S. (2018). Assessment of Students on BIPA Teaching Materials Special Materials of Agriculture. Litera, Jurnal Penelitian Bahasa, Sastra dan Pengajarannya, 18 (1), 150-163. https://journal.uny.ac.id/index. $\mathrm{php} /$ litera/article/view/15613.

Foley, W. A. (1997). Anthropological Linguistic: An Introduction. Massachusets: Blackwell Publishers.
Leech, G. 1993. The Principle of Pragmatic (Penerjemah: Oka). Jakarta: Universitas Indonesia.

Heriyawati, D. F, Siba, S.Y, dan Sulistyo, T. (2019). Lecturers' Politeness Strategies In Efl Classroom With Multicultural Background. Litera, Jurnal Penelitian Bahasa, Sastra dan Pengajarannya, 18 (3), 447-464. https://journal.uny.ac.id/index. $\mathrm{php} /$ litera/issue/view/1775.

House, J. 2007. What Is an 'Intercultural Speaker? A C.I.P. Catalogue record for this book is available from the Library of Congress. The Netherlands: Springer.

Jakobson, R. (1971). Linguistics and Communication Theory. The Hague: Mouton.

Koentjaraningrat. (2016). Pengantar Ilmu Antropologi. Bandung: Rineka Cipta.

Kusmiatun, A. (2016). Topik Pilihan Mahasiswa Tiongkok dalam Pembelajaran BIPA Pogram Transfer Kredit di Universitas Negeri Yogyakarta. Litera, Jurnal Penelitian Bahasa, Sastra dan Pengajarannya, 15 (1), 138-146. https://journal.uny. ac.id/index.php/litera/view/9773.

Liliweri, A. (2002). Makna Budaya dalam Komunikasi Antarbudaya. Yogyakarta: LKiS.

Liu, J. (2017). On Culture Infiltration And The Strategy Integrated With Specialty Characteristics In College English teaching. English Language Teaching, 10(5), 91-96. doi: 10.5539/ elt.v10n5p91.

Nurlina, L. dan Fathonah, S. (2015). Pengembangan Materi Membaca BIPA yang Terintegrasi Kearifaan Lokal sebagai Jembatan Komunikasi 
Antarnegara. Makalah Seminar Bahasa dan Kekuasaan di Prodi PBSI FBS UNY.

Nurgiyantoro, B. (2019). The Wayang Story in Modern Indonesian Fictions (Reviews on Mangunwijaya and Sindhunata's Novels). Litera, Jurnal Penelitian Bahasa, Sastra dan Pengajarannya, Volume 18 No. 2 edisi Juli 2019, 167-184. https:// journal.uny.ac.id/index.php/litera/ article/view/24997.

Rokhman, F. (2012). "Pengembangan model Pembelajaran Bahasa Indonesia untuk Penutur Asing dengan Pendekatan Lintas Budaya sebagai Penelitian Multikulturalisme Budaya Indonesia". Makalah Seminar Nasional PIBSI ke-XXXIV di Unsoed Purwokerto.

Sapir, E. (1921). Language an Introduction to the Study of Speech. https://www. pdfdrive.com/language-anintroduction-to-the-study-of-speechd o v e r - b o o k s - o n language-e157248743.html.

Salzman, Z., Stanlaw J. M., dan Adachi N. (2012). Language, Culture, and Society (An Introduction to Linguistic Anthropology). Colorado: Westview Press.

Sayuti, S. A. (2017). "Sastra dan Budaya: Jalur Alternatif Menuju BIPA yang Bermakna". Makalah Seminar
Nasional di Universitas Negeri Tidar Magelang pada 9 September 2017.

Sayuti, S. A. (2017). "Pengembangan Tema Pembelajaran Berbasis Budaya di PAUD: Menebar Benih Karakter dan Jatidiri Bangsa". Makalah Workshop di Fakultas Ilmu Pendidikan UNY pada 18 September 2017.

Seiferle, A. (2017). An Analysis of Franz Boas: Race, Language and Culture. London: by Macat International Ltd.

Sibarani, R. (2004). Antropolinguistik: Antropologi Linguistik-Linguistik Antropologi. Medan: Poda.

Sumarsono. (2004). Sosiolinguistik. Yogyakarta: Pustaka Pelajar.

Suyono. (2009). Pembelajaran Efektif dan Produktif Berbasis Literasi: Analisis Konteks, Prinsip, dan Wujud Alternatif Strategi Implementasinya di Sekolah. Bahasa dan Seni: Jurnal Bahasa, Sastra, Seni, dan Pengajarannya, Fakultas Sastra Universitas Negeri Malang 37 (2) tahun 2009.

Thomas, L. \& Wareing S. (2006). Bahasa, Masyarakat, dan Kekuasaan. Yogyakarta: Pustaka Pelajar.

Wardhaugh, R. (2006). An Introduction to Sociolinguistics. Oxford: Blackwell Publishing Ltd. 